Pak. j. sci. ind. res. Ser. B: biol. sci. 2019 62B(3) 199-205

\title{
Insect Biodiversity in Brinjal Agro-Ecosystem
}

\author{
Babar Hussain Chang ${ }^{\text {ac*}}$, Asif Hussain Changa, Abdul Ghani Lanjar ${ }^{\mathrm{a}}$, Aslam Bukero ${ }^{\mathrm{a}}$, \\ Imtaiz Ahmed Nizamani ${ }^{\mathrm{b}}$, Ammara Rajput ${ }^{\mathrm{a}}$, Fida Hussain Magsia ${ }^{\mathrm{a}}$, Mehroz Khan ${ }^{\mathrm{a}}$, \\ Farukh Asghar and Zehua Zhang ${ }^{\mathrm{c} *}$ \\ ${ }^{a}$ Department of Entomology, Sindh Agriculture University, Tandojam, Sindh, Pakistan \\ ${ }^{b}$ Department of Plant Protection, Sindh Agriculture University, Tandojam, Sindh, Pakistan \\ 'State Key Laboratory of Biology of Plant Diseases and Insect Pests, Institute of Plant Protection, \\ Chinese Academy of Agricultural Science, Beijing, China
}

(received November 28, 2017; revised April 24, 2018; accepted June 21, 2018)

\begin{abstract}
The experiment on insect biodiversity in brinjal (Solanum melongena L.) agro-ecosystem was conducted at village Mushtaque Kaleri near Tandojam, Hyderabad, Sindh, Pakistan during winter season 2015-2016. For this purpose $1 / 2$ acre of brinjal crop was cultivated. Collection was done once a week through sweep net method. Data was collected by examining 30 plants and analyzed by using Shannon diversity index. The results showed that in brinjal agro-ecosystem 27 species of insects were recorded from $10^{\text {th }}$ of December 2015 to $5^{\text {th }}$ of March 2016. Among them 19 species were pests and 8 species were predators and pollinators. The highest diversity $\left(\mathrm{H}^{\prime}=3.33\right)$ was recorded on 23 February, 2016 while the minimum $\left(H^{\prime}=2.15\right)$ was recorded on 01 December, 2015. The highest diversity $\left(H_{\max }\right) 3.29$ was recorded on 29 December, 2015 and 16 February, 2016 however, the lowest diversity $\left(\mathrm{H}_{\max }\right) 3.09$ was recorded on 01 December, 2015 and 08 December, 2015. The maximum evenness $\left(\mathrm{J}^{\prime}=1.02\right)$ was recorded on 26 January, 2016 and 23 February, 2016, respectively. Whereas minimum evenness $\left(J^{\prime}=0.69\right)$ was recorded on 01 December, 2015. The maximum richness $(D=0.27)$ was recorded in two observations on 29 December, 2015 and 16 February, 2016. However, minimum richness $(D=0.22)$ was recorded on 01 December, 2015 and 08 December, 2015 in brinjal agro-ecosystem.
\end{abstract}

Keywords: insect biodiversity, brinjal, agroecosystem, richness

\section{Introduction}

Agriculture is the backbone of Pakistan and source of economic growth and development. According to governmental sources, it contributes $21.4 \%$ of Pakistan gross domestic products accounts for $25 \%$ of employee's labor force and also contributes to other sources of the economy (GOP, 2015). Vegetables are regarded as the cheapest source of food which provides nutrients and vitamins for balancing daily diet. Vegetables are grown all over Pakistan and available in the market around the year. Brinjal (Solanum melongena L.) is an important vegetable in Asia where more than $90 \%$ production of brinjal is obtained.

Brinjal belongs to the family Solanaceae and it is mainly known as "king of vegetables" which is cultivated in tropical, sub-tropical and temperate regions of the world (Alam et al., 2003). Brinjal is originated from India and now it is cultivated throughout the world more than 1,600,000 ha with 50 million tonnes production annually. About 9,000 ha are cultivated in Pakistan with annual

*Authors for correspondence;

E-mail: babar_chang@yahoo.com; and Zhangzehua@caas.cn production of 87,000 tonnes (FAO, 2014), grown in all cropping seasons. From the nutritional point of view, it contains phosphorous, iron, calcium and vitamins A, $\mathrm{B}$ and $\mathrm{C}$. In the present agro-ecosystem brinjal is attacked by different kinds of insect pests from nursery to harvesting. Brinjal crop is attacked by different insect species which render the production of this crop. Generally, the infestation is reported from the seedling up to the harvesting. Insects which attack on brinjal are such as shoot borer (Leucinodes orbonalis), aphids (Aphis gossypii), leaf minor (Phytomyza atricornis), white spotted flea beetle (Monolepta signat and Chaetocnema basalis), white fly (Bemisia tabaci), thrips (Thrips palmi), spider mite (T. urticae) and jassids (Amrasca biguttulla biguttula) (Thakur et al., 2012). Generally, the population of jassids is recorded high in the second week of August. However, the activity of flea beetle is recorded from $1^{\text {st }}$ week of August to $2^{\text {nd }}$ week of November. Red spider mite is also found as a very serious pest of brinjal after shoot and fruit borers.

Fruit borer L. orbonalis is a very serious pest of brinjal and it is commonly found in all tropical regions of Asia, America, and Africa (Anwar et al., 2015). L. orbonalis 
is a monophagous pest highly reported in brinjal, however, other plants belonging to Solanaceae like tomato (Solanum lycopersicum L.), potato (Solanum tuberosum L.) and turkey berry (Solanum torvum L.) are also reported as alternate hosts of this pest. Damage by the white fly, borers, and leafhoppers can reduce approximately $70-90 \%$ yield of brinjal (Rosaiah, 2001). Ghosh et al. (2004) reported that white fly population was very high during the $32^{\text {nd }}$ standard week and he also reported that population of the white fly was significantly and negatively correlated with average temperature, humidity and weekly rainfall. The peak population of the white fly was recorded on 60 days old crop and the lowest population was recorded on 30 days old crop which was 3.2-6.7 adults per leaf (Hasan et al., 2008). Meena et al. (2010) found the activity of leafhopper from August to September and its minimum population was 2.0-2.4 and maximum population was recorded from 15.2-16.4 leafhoppers per plant.

In Pakistan, uses of pesticides increased from $665 \mathrm{MT}$ (metric tonnes) in 1980 to 69897 MT in 2002. This increase in the application of pesticides negatively affects not only agro-ecosystems, but also food as well as natural enemies of the harmful pest (Ahmed and Poswal, 2000). Organochlorine pesticides has shown persistence in an environment which resulted in contaminating ground as well as surface water, air, soil and food products which affect human heath through direct contact (Helweg, 2003). Natural pollinator like butterflies and honey bees are very sensitive to pesticides. Applications of pesticides are one main cause of decline of the population of natural pollinators (Hackenberg, 2007). Biodiversity comprises of several lives on all levels, genetic diversity as well as habitat, ecosystem diversity and species diversity. (Bengtsson et al., 2005). In agroecosystems, biodiversity is often a measure of the relative number of types exist organisms. When considering the impact on biodiversity of a system, the two concepts are a particularly important consideration: the stability and productivity (Schowalter, 2006). Insects are ubiquitous in the environment, play an important role through the part of the food chain and maintain the stability of the ecosystem, mediation decomposition process, through a variety of ecological relationships, such as pollination and predation. Therefore, the present study was carried out to determine the role of different insects in agro-ecosystem of brinjal. The study will also ascertain insect interaction with one another as pollinators, predators, parasitoids, herbivores, and scavengers.
Beside that their biodiversity, diversity maximum, species evenness, and richness will also be ascertained. The information gained through the study will be utilized in developing IPM strategies against helpful and harmful insect within brinjal agro-ecosystem.

\section{Materials and Methods}

The experiment on "Insect biodiversity in brinjal agroecosystem" was conducted at village Mushtaque Kaleri, Tandojam, Hyderabad, Sindh, Pakistan during winter season 2015-2016.

To determine the insect biodiversity on brinjal it was cultivated as a sole crop. For this purpose $1 / 2$ acre was cultivated. After transplanting, the crop was examined on 15 DAT, 12 DAT and 15 DAT at weekly intervals for recording the population of insect. Meanwhile, the population of specimens of insects was collected through sweep net method from $10^{\text {th }}$ of December 2015 to $5^{\text {th }}$ of March 2016. At each observation 30 plants were examined for insects counting and also collection. The collected specimens were transferred to plastic jars covered with muslin cloth so that air could pass into it. The collected specimens were brought to the department of Entomology, Faculty of Crop Protection, Sindh Agriculture University Tandojam for identification purpose. The collected insects were killed by killing bottle and ethyl acetate. The killed insects were spread over the table and identified at specie level. The collected specimens were separated out to determine their orders and families.

Since brinjal is known as a reservoir for many insect species, present studies were conducted to determine diversity, diversity maximum, species richness and species evenness by using Shannon diversity index.

The following diversity indices were used:

(i) $\mathrm{H}^{\prime}=\frac{\mathrm{n} \log \mathrm{n}-\mathrm{fi} \log \mathrm{fi}}{\mathrm{N}}$ (Diversity)

(ii) $\mathrm{H}_{\text {max }}^{\prime}=\log \mathrm{N}$ (Max diversity)

(iii) $\mathrm{J}^{\prime} \frac{\mathrm{H}^{\prime}}{\mathrm{H}_{\max }^{\prime}}$ (Evenness)

(iv) $\mathrm{D}=1-\mathrm{J}^{\prime}$ (Richness)

where:

$\mathrm{H}^{\prime}$ is the diversity index of total collected specimens, $\mathrm{fi}$ is the proportion of the species. $\mathrm{H}_{\text {max }}^{\prime}$ is the maximum 
diversity, $\mathrm{N}$ is the total number of species in the entire crop area. $\mathrm{J}$ ' is the evenness, $\mathrm{D}$ denote the dominance of species and $\mathrm{n}$ is the number of species per observation.

\section{Results and Discussion}

The results of the experiment showed that insect biodiversity at village Mushtaque Kaleri, Tandojam, Hyderabad, Sindh, Pakistan was different in brinjal agro-ecosystem. The periodic insect biodiversity is given as under.

Insect biodiversity in brinjal agro-ecosystem. In brinjal agro-ecosystem 27 species of insect were recorded from $1^{\text {st }}$ week of December 2015 to $1^{\text {st }}$ week of March 2016. Among these 19 species were pests and 8 species were predators and pollinators. The collected insects were belonging to orders, Diptera, Lepidoptera, Neuroptera, Hymenoptera, Hemiptera, , Thysanoptera and Isoptera. The details of insect's species and their taxonomic status are given in Table 1.

The data in Fig. 1-4 depicts population abundance of insect collected from brinjal agro-ecosystem. During the course of study total number of collected insects were 385.20 out of which population abundance of Leucinodes orbonalis was high at (37.00) followed by Aphis gossypii (35.10), Thrips palmi (28.00), Epilachna dodecastigma (23.80), Coccinella septempunctata (20.50), Apis florae (18.10), Athalia proxima (17.30), Chrysoperla carnea (17.30), Mylabris pustulata (16.40), Gryllus campestris (15.50), Menochilus sexmaculatus (14.20), Eristalis sp. (12.30), Bombyx mori (12.10),

Table 1. Taxonomic position and status of insects collected and recorded in brinjal agro-ecosystem at Tandojam during $1^{\text {st }}$ week of December 2015 to $1^{\text {st }}$ week of March 2016

\begin{tabular}{|c|c|c|c|c|}
\hline Common name & Latin name & Family & Order & Status \\
\hline Fruit and shoot borer & Leucinodes orbonalis (Guenee) & Pyralidae & Lepidoptera & Pest \\
\hline Leafhopper & Amrasca devastans (Distant) & Cicadellidae & Hemiptera & Pest \\
\hline Lady bird beetle & Coccinella septempunctata (Lat) & Coccinellidae & Coleoptera & Predator \\
\hline White fly & Bemisia tabaci (Genn) & Aleyrodidae & Hemiptera & Pest \\
\hline Leaf roller & Eublemma olivacea (Walker) & Noctuidae & Lepidoptera & Pest \\
\hline Green grass hopper & Atractomorpha acutipennis (Gue) & Acrididae & Orthoptera & Pest \\
\hline Spotted beetles & Epilachna dodecastigma (Wied) & Coccinellidae & Coleoptera & Pest \\
\hline Painted bug & Bagrada cruciferarum (Kirkaldy) & Pentatomidae & Hemiptera & Pest \\
\hline Blister beetle & Mylabris pustulata (Thun) & Meloidae & Coleoptera & Pest \\
\hline Honey bee & Apis florae (Fab) & Apidae & Hymenoptera & Pollinator \\
\hline Thrips & Thrips palmi (Karny) & Thripidae & Thysanoptera & Pest \\
\hline Saw fly & Athalia proxima (Klug) & Tenthredinidae & Hymenoptera & Pest \\
\hline Stem borer & Euzophera perticella (Rag) & Pyralidae & Lepidoptera & Pest \\
\hline Crickets & Gryllus campestris (Linn) & Gryllidae & Orthoptera & Pest \\
\hline Cotton Aphids & Aphis gossypii (Glover) & Aphididae & Hemiptera & Pest \\
\hline Cabbage butter fly & Pieris brassicae (Linn) & Pieridae & Lepidoptera & Pest \\
\hline Bumble bees & Bombyx mori (Linn) & Apidea & Hymenoptera & Pollinator \\
\hline Zigzag beetle & Menochilus sexmaculatus (Fab) & Coccinellidae & Coleoptera & Predator \\
\hline House cricket & Acheta domesticus (Linn) & Gryllidae & Orthoptera & Pest \\
\hline Hover fly & Eristalis sp. (Lat) & Syrphidae & Diptera & Predator \\
\hline Chrysoperla & Chrysoperla carnea (Stephens) & Chrysopidae & Neuroptera & Predator \\
\hline Butter fly & Danaus plexippus (Linn) & Danaidae & Lepidoptera & Pollinator \\
\hline Red spider mite & Tetranychus urtecae (Koch) & Tetranychidae & Acarina & Pest \\
\hline White ant & Microtermes obesi $(\mathrm{Hol})$ & Termitidae & Isoptera & Pest \\
\hline Weevil & Brachycerus albidentatus (Gyll) & Curculionidae & Coleopteran & Pest \\
\hline Army worm & Spodoptera frugiperda (Smith) & Noctuidae & Lepidoptera & Pest \\
\hline Araneid spider & Neoscona adianta walck) & Araneidae & Araneae & Predator \\
\hline
\end{tabular}


Bemisia tabaci (11.70), Tetranychus urtecae (11.40), Acheta domesticus (11.20), Amrasca devastans (11.00), Euzophera perticella (10.40), Danaus plexippus (10.40),

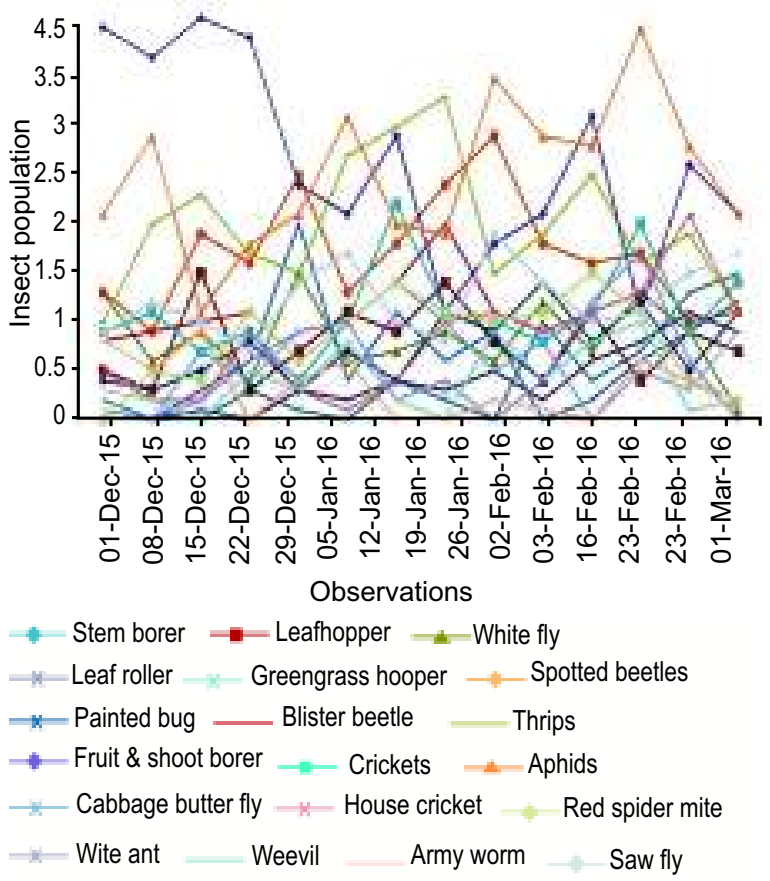

Fig. 1. Biodiversity of insect pest in brinjal agroecosystem from $1^{\text {st }}$ week of December 2015 to $1^{\text {st }}$ week of March 2016.

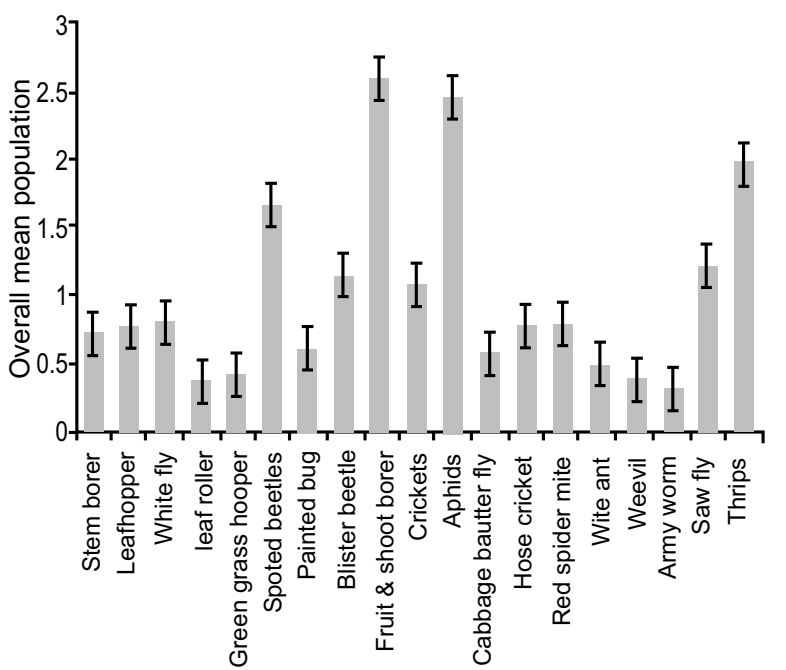

Fig. 2. Average biodiversity of insect pests in brinjal agro-ecosystem from $1^{\text {st }}$ week of December 2015 to $1^{\text {st }}$ week of March 2016.
Bagrada cruciferarum (8.80), Pieris brassicae (8.40), Microtermes obesi (7.30), Atractomorpha acutipennis (6.10), Brachycerus albidentatus (5.70), Eublemma olivacea (5.40), Neoscona adianta (5.20) and Spodoptera frugiperda (4.60).

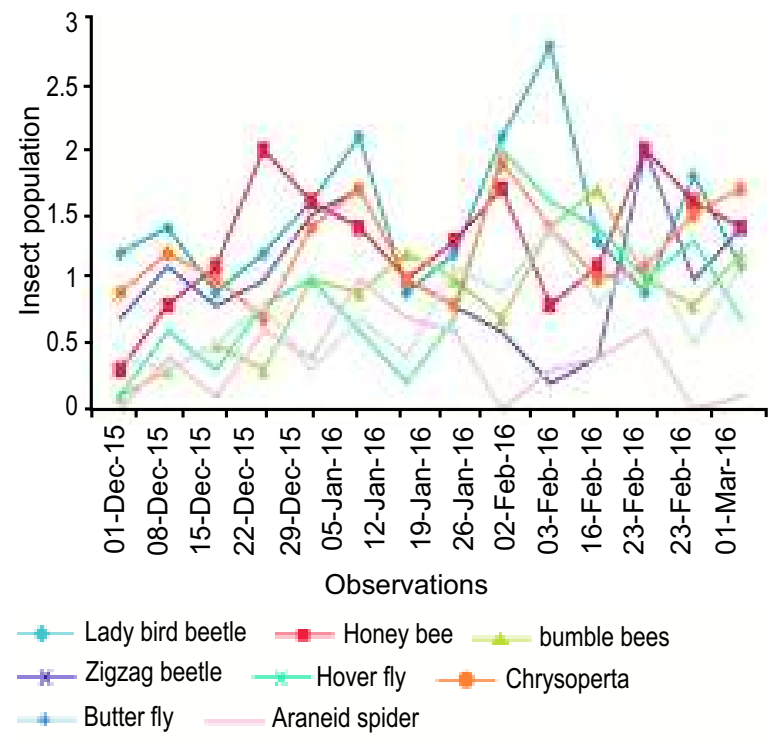

Fig. 3. Biodiversity of predators and pollinators in brinjal agro-ecosystem from $1^{\text {st }}$ week of December 2015 to $1^{\text {st }}$ week of March 2016.

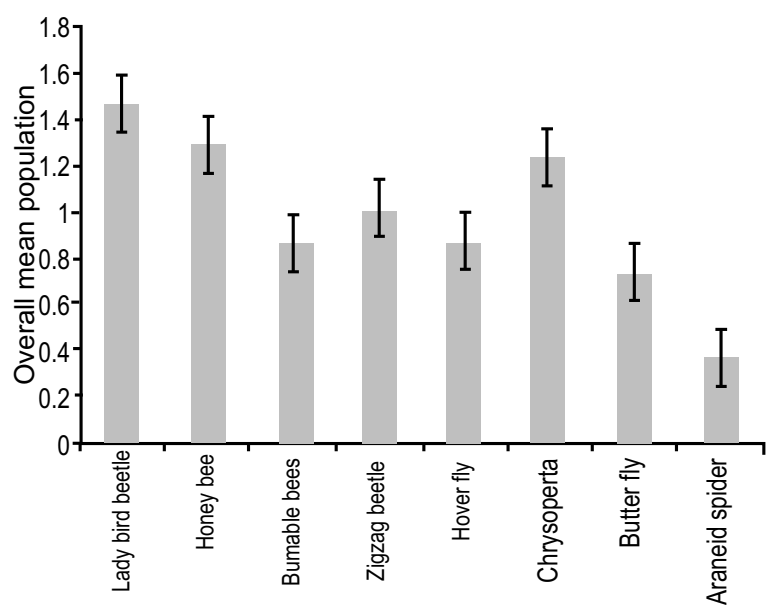

Fig. 4. Average biodiversity of predators and pollinators in brinjal agro-ecosystem from $1^{\text {st }}$ week of December 2015 to $1^{\text {st }}$ week of March 2016. 
Figure 5 depicts that highest diversity $\left(\mathrm{H}^{\prime}=3.33\right)$ which was recorded on 23 Feb-2016, while the minimum diversity $\left(\mathrm{H}^{\prime}=2.15\right)$ was recorded on $01 \mathrm{Dec}-2015$. The highest diversity $\left(\mathrm{H}^{\prime}{ }_{\max }\right) 3.29$ was recorded on 29 Dec2015 and 16 Feb-2016 however, the lowest diversity $\left(\mathrm{H}_{\max }\right) 3.09$ was recorded on 01 Dec-2015 and 08 Dec2015. The maximum evenness $\left(\mathrm{J}^{\prime}=1.02\right)$ was recorded on 26 Jan-2016 and 23 Feb-2016, respectively. Where minimum evenness $\left(\mathrm{J}^{\prime}=0.69\right)$ was recorded on 01 Dec2015. The maximum richness $(D=0.27)$ was recorded in two observations on 29 Dec-2015 and 16 Feb-2016. However, minimum richness $(\mathrm{D}=0.22)$ was recorded on 01 Dec-2015 and 08 Dec-2015 in brinjal agroecosystem.

Biodiversity comprises of several lives on all levels, genetic diversity as well as habitat, ecosystem diversity and species diversity. Biodiversity is commonly defined as different forms of animals, plants and microorganisms which are existed on earth. With different ways in which climate, organisms and geology combines to form functioning ecosystem. On earth there are humans, plants and insects which are living and effected by biodiversity and complex web of life. Over a million species of insects are described which are 20 times higher in population of all vertebrates, only one order coleopteran (beetles) covers $25 \%$ of all described species of life (Hunt et al., 2007).

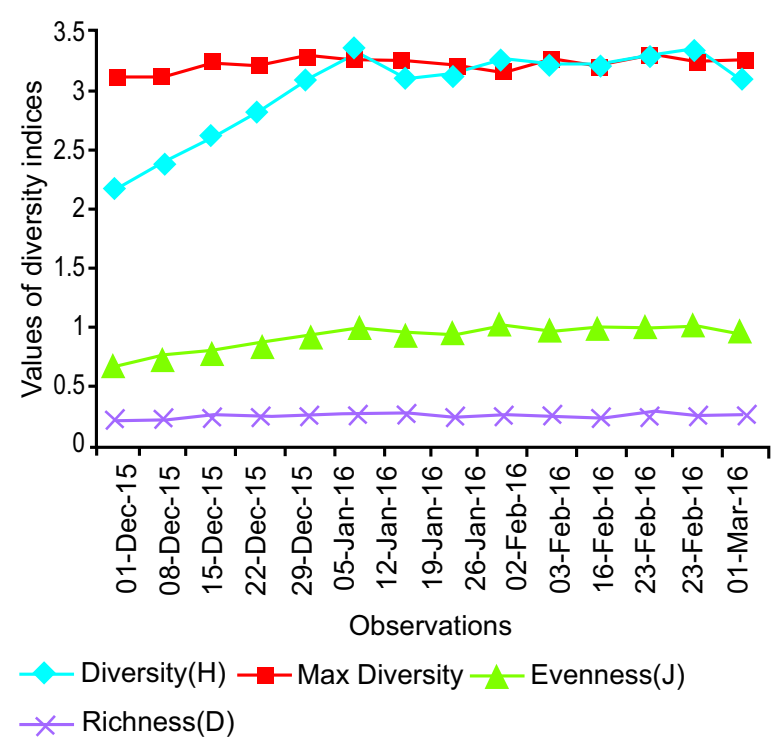

Fig. 5. Biodiversity of arthropods in brinjal agroecosystem.
Furthermore results were confirmed by Kataria and Kumar (2012) who recorded that 49 species of insects belong to order Lepidopterans, Coleopterans and Hemipterans on various host plants of different families Malvaceae, Fabaceae, Solanaceae and Asclepiadaceae. Ghosh and Chakraborty (2012) recorded 12 species of coccinellid beetles in brinjal crop during months of September and October 2005. Latif et al. (2009) investigated 20 species of insect pests belonging to 6 various orders and 10 families of predators were found in brinjal agro-ecosystem from which $42.44 \%$ were related to

Table 2. Correlation between insect population and a biotic factor in biodiversity of brinjal agro-ecosystem from $1^{\text {st }}$ week of December 2015 to $1^{\text {st }}$ week of March 2016

\begin{tabular}{|c|c|c|}
\hline \multirow[t]{2}{*}{ Insects } & \multicolumn{2}{|c|}{ Brinjal agro-ecosystem } \\
\hline & $\begin{array}{l}\text { Temperature } \\
{ }^{\circ} \mathrm{C}\end{array}$ & $\begin{array}{l}\text { Relative } \\
\text { humidity }\end{array}$ \\
\hline Fruit and shoot borer & 0.114796 & 0.25 \\
\hline Leafhopper & 0.104592 & 0.25 \\
\hline Lady bird beetle & 0.122449 & 0.265306 \\
\hline White fly & 0.127551 & 0.265306 \\
\hline Leaf roller & 0.119898 & 0.25 \\
\hline Green grass hopper & 0.137755 & 0.280612 \\
\hline Spotted beetles & 0.130102 & 0.285714 \\
\hline Painted bug & 0.122449 & 0.265306 \\
\hline Blister beetle & 0.112245 & 0.239796 \\
\hline Honey bee & 0.125 & 0.25 \\
\hline Thrips & 0.135204 & 0.27551 \\
\hline Saw fly & 0.117347 & 0.285714 \\
\hline Stem borer & 0.109694 & 0.229592 \\
\hline Crickets & 0.104592 & 0.25 \\
\hline Aphids & 0.112245 & 0.25 \\
\hline Cabbage butter fly & 0.096939 & 0.295918 \\
\hline Bumble bees & 0.104592 & 0.229592 \\
\hline Zigzag beetle & 0.114796 & 0.25 \\
\hline House cricket & 0.107143 & 0.270408 \\
\hline Hover fly & 0.127551 & 0.30102 \\
\hline Chrysoperla & 0.104592 & 0.25 \\
\hline Butter fly & 0.09949 & 0.270408 \\
\hline Red spider mite & 0.094388 & 0.306122 \\
\hline White ant & 0.102041 & 0.295918 \\
\hline Weevil & 0.09949 & 0.316327 \\
\hline Army worm & 0.119898 & 0.30102 \\
\hline Araneid spider & 0.107143 & 0.270408 \\
\hline
\end{tabular}


Coleopteran. Pandey et al. (2006) revealed that Plutella xylostella, Pieris brassicae, Brevicoryne brassicae, Tetranychus urticae, Helicoverpa armigera, Agrotis ipsilon, Etiella zinckenella, Phyllotreta spp, Hylemya antiqua (Delia antiqua), Thrips tabaci and Adoretus spp. are the major insect pests of various vegetables recorded in Jammu and Kashmir. According to Thakur et al. (2012) shoot borer (Leucinodes orbonalis), aphids (Aphis gossypii), leaf minor (Phytomyza atricornis), white spotted flea beetle (Monolepta signat and Chaetocnema basalis), white fly (Bemisia tabaci), thrips (Thrips palmi), spider mite (T. urticae) and jassid (Amrasca biguttulla biguttula) are the major insect pests of brinjal.

The diversity indices by using Shannon diversity index in present study shows that the diversity of insect was stable in brinjal agro-ecosystem. An increase in the value of index indicates an increase in diversity. The biodiversity among crops and insects can be categorized in two types that are species richness and evenness. Vanclay (1992) told that species richness shows that the numbers of species present in study area and species evenness shows the abundance of each species. Magurran (1988) suggested that species richness provides an extremely useful measure of diversity when a complete catalogue of species in the community is obtained.

\section{Conclusion}

In this study twenty seven species belonging to different orders were recorded in brinjal agro-ecosystem from $1^{\text {st }}$ week of December 2015 to $1^{\text {st }}$ week of March 2016. From 27 species 19 species were identified as pest and 8 species were identified as predators and pollinators. 385.20 total numbers of individuals were recorded out of which 275.10 were identified as insect pests and 110.10 were identified as predators and pollinators in brinjal agro-ecosystem. All recorded specimens were found active throughout cropping season.

\section{Acknowledgement}

The authors are thankful to Prof. Dr. Mark Richard McNeill (AgResearch, Lincoln Research Centre, Christchurch, New Zealand) and Prof. Dr. Hidayat Ullah (Department of Agriculture, The University of Swabi, Pakistan) for their invaluable suggestions on manuscript organization and linguistic revision.

Conflict of Interest. The authors declare no conflict of interest.

\section{References}

Ahmad, I., Poswal, A. 2000. Cotton integrated pest management in Pakistan: Current Status. Country Report Presented in Cotton IPM Planning and Curriculum Workshop Organized by FAO, Bangkok, Thailand. February 28 - March 2.

Alam, S.N., Rashid, M.A., Rouf, F.M.A., Jhala, R.C., Patel, J.R. 2003. Development of an integrated pest management strategy for egg plant, fruit and shoot borer in South Asia. Technical Bulletin 28, pp. 66., AVRDC-The World Vegetable Center, Shanhua, Taiwan.

Anwar, S., Mari, J.M., Khanzada, M.A., Ullah, F. 2015. Efficacy of insecticides against infestation of brinjal fruit borer, Leucinodes orbonalis Guenee (Pyralidae: Lepidoptera) under field conditions. Journal of Entomology and Zoology Studies, 3: 292-295.

Bengtsson, J., Ahnstrom, J., Webull, A.C. 2005. The effect of organic agriculture on biodiversity and abundance using meta-analysis. Journal of Applied Ecology, 42: 261-269.

FAO, 2014. FAOSTAT. Available at: http://www.fao.org

Ghosh, S.R.K., Chakraborty, K. 2012. Incidence and abundance of important predatory beetles with special reference to Coccinella septempunctata in sub-Himalayan region of north-east India. International Journal of Plant, Animal and Environmental Sciences, 2: 157-162.

Ghosh, S.R.K., Basak, S.N., Senapathi, S.K. 2004. Seasonal fluctuation of Bemisia tabaci Genn. on brinjal and field evaluation of some pesticides against Bemisia tabaci under terai region of West Bengal. Environment and Ecology, 22: 758-762.

GOP, 2015. Economic Survey of Pakistan. Economic Advisor's Wing, Finance Division, Govt. of Pakistan, Islamabad, Pakistan.

Hackenberg, D. 2007. Letter from David Hackenberg to American growers from March 14, 2007. Platform Imkerinnen Austria. http://web.archive.org/ web/20070604214622/http://www.imkerinnen.at/H

Hasan, W., Ansari, M.S., Ali, H. 2008. Distribution pattern of whitefly Bemisia tabaci under natural condition on okra cultivars. Entomon, 33: 113-117.

Helweg, C., Mogensen, B.B., Sørensen, P.B., Madsen, T., Bossi, R., Rasmussen, D., Petersen, S. 2003. Fate of pesticides in surface waters, laboraty and field experiments. Pesticides Research, 68: 55-60.

Hunt, T., Bergsten, J., Levkanicova, Z. 2007. A 
comprehensive phylogeny of beetles reveals the evolutionary origins of a superrediation. Journal of Science, 318: 913-1916.

Kataria, R., Kumar, D. 2012. Occurrence and infestation level of sucking pests: Aphids on various host plants in agricultural fields of Vadodara, Gujarat (India). International Journal Scientific Research Publications, 2: 1-6.

Latif, M.A., Rahman, M.M., Islam, M.R., Nuruddin, M.M. 2009. Survey of arthropod biodiversity in the brinjal field. Journal of Entomology, 6: 28-34.

Magurran, A.E. 1988. Ecological Diversity and Measurement. Springer, Dordrecht, Germany. ISBN 97894-015-7360-3

Meena, N.K., Kanwat, P.M., Meena, A., Sharma, J.K. 2010. Seasonal incidence of jassids and whiteflies on okra Abelmoschus esculentus (L.) Moench in semi-arid region of Rajastan. Annals of Agri Bio Research, 15: 25-29.

Pandey, A.K., Namgyal, D., Mehdi, M., Mir, M.S., Ahmad, S.B. 2006. A case study: major insect pest associated with different cold arid region Ladakh, of Jammu and Kashmir. Journal of Entomological Research, 30: 169-174.

Potts, S.G., Biesmeijer, J.C., Kremen, C., Neumann, P., Schweiger, O., Kunin, W.E. 2010. Global pollinator declines: trends, impacts and drivers. Trends in Ecology and Evolution, 25: 345-353.

Rosaiah, B. 2001. Evaluation of different botanicals against the pest complex of brinjal. Pestology, 25: 14-16.

Schowalter, T.D. 2006. Insect Ecology: An Ecosystem Approach, 572 pp., $2^{\text {nd }}$ edition, Academic Press, USA.

Thakur, N.S.A., Firake, D.M., Behere, G.T., Firake, P.D., Saikia, K. 2012. Biodiversity of agriculturally important insects in north eastern Himalaya. Indian Journal of Hill Farming, 25: 37-40.

Vanclay, J.K. 1992. Species richness and productive forest management. In: Proceeding of Oxford Conference Tropical Forests. S. K. Agarwal, S. Trewali and P. S. Dubey (eds.), pp. 18-31, Biodiversity and Environment, A. P. H. Publication Corporation, New Delhi, India. 